\title{
ISOLATION, SCREENING AND CHARACTERIZATION OF ANTIBIOTIC PRODUCING ACTINOMYCETES FROM KAPULUPPADA PLASTIC WASTE DUMPING YARD, VISAKHAPATNAM
}

\author{
MIDHUN KUMAR DUDDU ${ }^{*}$, GIRIJASANKAR GUNTUKU² \\ Pharmaceutical Biotechnology Division, A. U. College of Pharmaceutical Sciences, Andhra University, Visakhapatnam (A. P.), India, 530003 \\ Email: midhunkumarduddu@gmail.com
}

Received: 28 Nov 2015 Revised and Accepted: 09 Sep 2016

ABSTRACT

Objective: To isolate, screen and characterize antibiotic producing actinomycetes from Kapuluppada plastic waste dumping yard, Visakhapatnam.

Methods: A total of 12 soil samples were collected, serially diluted and spread on starch casein agar supplemented with Rifampicin and Cycloheximide for inhibition of bacteria and fungi, respectively. Cross-streak method was used to check the antagonistic activity of isolated actinomycetes against bacteria and fungi. Crude extracts from submerged state fermentation were used for the production of antimicrobial compounds. Agar well diffusion method was used for antimicrobial activity of crude extracts against test organisms. The isolates were characterized by morphological, physiological and biochemical methods.

Results: A total of 110 actinomycete isolates were isolated from plastic waste dumping yard. All isolates had shown antimicrobial activity against one or more tested bacteria/fungi. The crude extract of the isolates PD66 (12.2 mm), PD85 (11.5 mm) were most active against methicillin-resistant Staphylococcus aureus, PD4 (14.1 mm), PD66 (15.6 mm) were active against Pseudomonas aeruginosa, whereas the extracts of PD10 (19.2 mm), PD47 (19.8 mm), PD106 (19.1 mm) were active against Candida albicans, PD10 (14.6 mm), PD82 (15.7 mm) active against Saccharomyces cereviciae. The isolates had shown varying morphological, physiological and biochemical characteristics.

Conclusion: The actinomycetes isolated from Kapuluppada plastic waste dumping yard were found to be most promising microorganisms for the production of antibacterial and antifungal antibiotics.

Keywords: Actinomycetes, Cross-streak method, Agar well diffusion method, Crude extracts, Antibiotics, Antibacterial activity

(C) 2016 The Authors. Published by Innovare Academic Sciences Pvt Ltd. This is an open access article under the CC BY license (http://creativecommons.org/licenses/by/4. 0/] DOI: http://dx.doi.org/10.22159/ijpps.2016v8i11.10110

\section{INTRODUCTION}

Bioactive secondary metabolites are produced by microorganisms such as bacteria, fungi, actinomycetes. Of these, actinomycetes play an important role [1-3]. Actinomycetes are Gram-positive bacteria but are distinguished from other bacteria by their morphology and DNA (deoxyribonucleic acid) rich in guanine plus cytosine $(\mathrm{G}+\mathrm{C})$ [4-6]. Actinomycetes are of universal occurrence in nature and are widely distributed. They are found in soils, fresh water, marine water and mangrove sediments, lake, manures, composts and dust as well as on plastic waste areas and in food products, etc. However, the diversity and distribution of actinomycetes that produce bioactive secondary metabolites can be determined by physical, chemical and geographical means $[5,6]$. They produce many important bioactive substances having commercial value and their ability to produce a variety of bioactive substances has been utilized in numerous research and industrial laboratories. This has resulted in the isolation of metabolites from actinomycetes, which have found application in treating a variety of human infections [7]. Because of this reason, $70 \%$ of naturally occurring antibiotics had been isolated from a different genus of actinomycetes [8]. Among them, Streptomyces is the largest genus known for the production of many bioactive secondary metabolites [9], which had antibacterial, antifungal, antiparasitic, anticancer and immunosuppressive activities [1, 10,11]. Some antibiotics such as penicillin, erythromycin, and methicillin which were effective against infectious diseases [12, 13], are now less effective because bacteria had become resistant to such antibiotics. Methicillin resistant pathogen such as methicillin-resistant Staphylococcus aureus and others cause an enormous threat to the treatment of serious infections. To overcome this problem, immediate replacement of the existing antibiotic is necessary [13], and the production of novel drugs against drug-resistant pathogens is important. Thus, producing novel antibiotics as well as using combinatorial therapy are effective in the treatment of resistant pathogenic infections. Antibiotic synergism between known antibiotics is a novel approach and has an important activity against pathogens and host cells [14]. The research focused mainly in finding novel antibiotics and increasing the productivity of antibiotics has been a very important activity $[3,7]$. This is because some biologically important drugs are expensive and have adverse effects to the host, some microorganisms have no successful antimicrobial agents, and others are developing multidrug resistance. It requires more attention to find solutions by searching and producing novel and more effective antibiotics from actinomycetes. However, there is no such scientific report on antibiotics producing actinomycetes from soil samples collected in Kapuluppada plastic waste dumping yard, Visakhapatnam, Andhra Pradesh (India) Therefore, the objective of the present study was to isolate, screen and characterize antibiotic producing actinomycetes from plastic waste dumping yard. The outcome of this finding may be important to give direction for researchers and for future treatment of multidrugresistant human pathogens.

\section{MATERIALS AND METHODS}

\section{Study area and samples collection}

The soil samples were collected from Kapuluppada plastic waste dumping yard near Kommadi (Madhurawada), Visakhapatnam, Andhra Pradesh (India). The 80-acre dump yard is about $20 \mathrm{~km}$ away from Visakhapatnam and is being dumped at the yard for nearly $17 \mathrm{y}$. Within a short distance of this yard, there are around 8,000 housing units constructed under Rajiv Gruhakalpa, while Marikavalasa, Boruvanipalem, Drivers' colony, Saradanagar, Pata Paradesipalem, Kotta Paradesipalem and Kapuluppda are in the vicinity. About 30-40 percent living in the housing colonies have vacated because of the pollution caused by this yard.

A total of 12 soil samples were collected from $5-10 \mathrm{~cm}$ depth during the month of March 2014 by inserting sterile corer into the soil. The 
samples were transferred to a sterile polythene bag and transported immediately to the laboratory for further processing. The soil samples were air-dried at room temperature, crushed in mortar and pestle to make fine particles, sieved and used for actinomycetes isolation [15].

\section{Sampling and isolation of actinomycetes}

From each sample collected above, $1 \mathrm{~g}$ of soil sample was added in different test tubes containing $10 \mathrm{ml}$ sterile distilled water and shaken well using vortex mixer. They were considered as stock samples for different soil sample sites. From the stock samples, a volume of $1 \mathrm{ml}$ was transferred aseptically and added to a test tube containing $9 \mathrm{ml}$ of sterile distilled water and mixed well. From this test tube, $1 \mathrm{ml}$ of the aliquot was again transferred and mixed with another $9 \mathrm{ml}$ of sterile distilled water to make $10^{-2}$ dilution factor. Similarly, dilutions up to $10^{-8}$ were made using serial dilution technique for all soil samples. A volume of $1 \mathrm{ml}$ of suspension from $10^{-7}$ and $10^{-8}$ dilutions was taken and spread evenly with sterile glass rod over the surface of sterile starch casein agar plates aseptically using spread plating technique. Cycloheximide $(50 \mu \mathrm{g} / \mathrm{ml})$ and Rifampicin $(25 \mu \mathrm{g} / \mathrm{ml})$ were added in medium to inhibit fungal and bacterial contamination, respectively. The plates were incubated aerobically at $27{ }^{\circ} \mathrm{C}$ up to $7-10 \mathrm{~d}$ and observed intermittently during incubation [16]. After incubation, morphologically distinct actinomycetes colonies on the starch casein agar plates were picked and further sub-cultured onto their respective isolation media. The actinomycete colonies were purified by streak plate method $[17,18]$. Once the pure colonies were obtained, each colony was further identified based on its earthy like smell, colony morphology, the colour of hyphae and the presence or absence of aerial and substrate mycelium. Then, selected and identified colonies of actinomycetes were transferred from the plate to starch casein agar slant and incubated at $27^{\circ} \mathrm{C}$ for their growth. After incubation, the slants containing pure isolated actinomycetes were stored at $4{ }^{\circ} \mathrm{C}$ and preserved as glycerol stocks at- $20^{\circ} \mathrm{C}$ for further studies.

\section{Preliminary screening}

Actinomycetes isolated above from different soil samples were screened for their antimicrobial activity against bacteria and fungi. The test bacteria used for primary screening were Methicillinresistant Staphylococcus aureus (clinical isolate, King George Hospital, Visakhapatnam), Pseudomonas aeruginosa (clinical isolate from King George Hospital (KGH)), Escherichia coli NCIM2065, Klebsiella pneumonia, Bacillus subtilis NCIM2063, and Bacillus pumilis NCIM2327. Antifungal activity of these actinomycetes was determined using Saccharomyces cerevisiae MTCC170, Candida albicans MTCC183, Aspergillus niger NCIM 548, Penicillium chrysogenum NCIM 738 and Aspergillus oryzae NCIM 643 as test organisms. Activities were performed using nutrient agar for bacteria and potato dextrose agar for fungi by cross streak method [19] and agar overlay method [20-22]. Each plate was streaked and stabbed with each isolate at the center of a plate and incubated at 27 ${ }^{\circ} \mathrm{C}$ for approximately 6-7 d. Then, $24 \mathrm{~h}$ subcultured bacteria, and 48 $\mathrm{h}$ old culture of fungi were streaked perpendicular to the actinomycete isolate and also by agar overlay method. Then, the plates were incubated for $24 \mathrm{~h}$ at $37^{\circ} \mathrm{C}$ for bacteria and $48 \mathrm{~h}$ at $28^{\circ} \mathrm{C}$ for fungi. After incubation, the zone of inhibition was measured and recorded.

\section{Extraction of antimicrobial compounds}

Based on the results of primary screening by streak plate and agar overlay methods, actinomycete isolates with potential antimicrobial activity were selected for submerged fermentation and extraction of antimicrobial compounds, and then the crude extracts were assessed following agar well diffusion method [23]. The selected antagonistic actinomycete isolates against bacteria and fungi were inoculated into starch casein broth separately and incubated at room temperature in a shaker at $180 \mathrm{rpm}$ for seven days. After incubation, the broths were filtered through Whatman No. 1 filter paper. Then, the filtrates were centrifuged separately at $5000 \mathrm{rpm}$ for $10 \mathrm{~min}$ to extract the antimicrobial compounds. The supernatant was transferred aseptically into a screw-capped bottles and stored at $4{ }^{\circ} \mathrm{C}$ for further study [24]. The wells of $6 \mathrm{~mm}$ diameter were cut using a sterile borer on nutrient agar for bacteria and potato dextrose agar for fungi. Twenty-four hours cultures of methicillinresistant Staphylococcus aureus, Psedomonas aeruginosa (clinical isolates from KGH), Escherichia coli NCIM2065, Klebsiella pneumonia, Bacillus subtilis NCIM2063, and Bacillus pumilis NCIM2327 and $48 \mathrm{~h}$ old cultures of Saccharomyces cerevisiae MTCC170, Candida albicans MTCC183, Aspergillus niger NCIM 548, Penicillium chrysogenum NCIM 738 and Aspergillus oryzae NCIM 643 were swabbed with sterilized cotton swab on the surface of prepared nutrient agar for bacteria and potato dextrose agar for fungi. Fifty microliters of crude extract was loaded into each well and left for $30 \mathrm{~min}$ until the metabolite was diffused. Then the plates were incubated for $24 \mathrm{~h}$ at $37{ }^{\circ} \mathrm{C}$ for bacteria and $48 \mathrm{~h}$ at $28{ }^{\circ} \mathrm{C}$ for fungi. After incubation, the zone of inhibition was measured and recorded. The antibiotics such as Ciprofloxacin, Cyclohexamide were used as antibacterial and antifungal agents, respectively.

\section{Characterization of actinomycetes}

The potential isolates selected from the primary and secondary screening for the production of antimicrobial agents were characterized by morphological, biochemical and physiological methods [25].

\section{Morphological characterization}

\section{Macroscopic method}

Morphological characters of the selected isolates were studied by inoculating into sterile media such as glycerol yeast extract agar, oatmeal agar, mineral salts agar, and starch casein agar [26]. The media was sterilized and poured into sterile Petri dishes. After solidification, selected isolates were streaked aseptically in the laminar air flow unit and incubated at $27^{\circ} \mathrm{C}$ for $7 \mathrm{~d}$. Morphological characters such as colony characteristics, pigment production, presence or absence of aerial and substrate mycelium were observed.

\section{Morphological characterization by microscopic coverslip culture method}

The arrangement of spores and sporulating properties of the selected isolates were examined microscopically by using cover slip culture method by inserting sterile cover slip at an angle of $45^{\circ} \mathrm{C}$ in the starch casein agar medium $[27,28]$. A loop full of each isolate was taken separately from $7 \mathrm{~d}$ old culture, inoculated at the insertion of coverslip and incubated at $27{ }^{\circ} \mathrm{C}$ for $7 \mathrm{~d}$. Then, the coverslip was removed by using sterile forceps and placed upward on a clean glass slide. Finally, the cover slip was observed for the morphology of isolates under the trinocular microscope (America Inc., LABOMED USA CXR3 9122100) at 400 magnification.

\section{Physiological and biochemical characterization}

\section{Effect of temperature on growth}

The ability of the selected isolates to grow at different temperatures was studied at $10^{\circ} \mathrm{C}, 15^{\circ} \mathrm{C}, 20^{\circ} \mathrm{C}, 25^{\circ} \mathrm{C}, 30^{\circ} \mathrm{C}, 35^{\circ} \mathrm{C}, 40^{\circ} \mathrm{C}, 45^{\circ} \mathrm{C}$ and $50{ }^{\circ} \mathrm{C}$. The isolates were streaked on starch casein agar slants and incubated at different temperatures [29] and after $7 \mathrm{~d}$ observed their growth.

\section{Melanin production}

The production of melanin is an important characteristic for the identification and classification of actinomycetes, especially Streptomyces. Melanin is a dark pigment produced by the microorganisms on tyrosine containing a medium. The tryptone yeast extract broth (ISP-1), yeast extract iron agar (ISP-6), tyrosine agar (ISP7) were used for testing melanin production by the actinomycete isolates [18]. Seven-day old culture of actinomycete isolates was inoculated on each media and incubated at $27^{\circ} \mathrm{C}$ for $4 \mathrm{~d}$ and the uninoculated media serves as a control. The color change was observed after $2 \mathrm{~d}$ and $4 \mathrm{~d}$. Greenish brown and brown to black diffusible pigments were considered as positive for melanin production.

\section{Gelatin hydrolysis}

Gelatin is a protein produced by the hydrolysis of collagen. Microorganisms can produce gelatinase that can hydrolyze gelatin to amino-acids. For this, the actinomycete isolates were streaked on gelatin agar and incubated at $27^{\circ} \mathrm{C}$ for $7 \mathrm{~d}$. Following incubation, the 
plates were flooded with $10 \mathrm{ml}$ of mercuric chloride solution and observed for the zone of hydrolysis [30].

\section{Peptonization and coagulation of milk}

Milk coagulation and peptonization test were carried out with skim milk. The skim milk containing test tubes were inoculated with isolates and incubated at $27^{\circ} \mathrm{C}$ for $7 \mathrm{~d}$. The extent of coagulation and peptonization was recorded on $3^{\text {rd }}$ and $8^{\text {th }} d$ [31].

\section{Casein hydrolysis}

The proteolytic activity of the selected isolates was studied using milk casein agar. The isolates were streaked on milk casein agar and incubated at $27^{\circ} \mathrm{C}$ for 5-7 d. Following incubation, isolates secreting protease enzyme will exhibit a zone of proteolysis, which is demonstrated by clear zone surrounding their growth. This loss of opacity is the result of a hydrolytic reaction yielding soluble, noncolloidal amino acids, and it represents a positive for casein hydrolysis [31].

\section{Starch hydrolysis}

The isolates were streaked on starch agar plates and incubated at 27 ${ }^{\circ} \mathrm{C}$ for 5-7 d. Then, the plates were flooded with iodine solution. Starch in the presence of iodine will impart a blue-black color to the medium indicating the absence of starch-splitting enzymes and representing a negative result. However, the presence of clear colorless zone surrounding the growth of the microbe represents a positive result for starch hydrolysis [31].

\section{Urea hydrolysis}

For this, isolates were inoculated into sterile urea agar slants and incubated at $30^{\circ} \mathrm{C}$ for $7 \mathrm{~d}$ and a change in color was observed.

\section{Nitrate reduction test}

The selected isolates were inoculated into $5 \mathrm{ml}$ of nitrate broth and incubated at $27^{\circ} \mathrm{C}$ for $7 \mathrm{~d}$ and uninoculated nitrate broth serves as a control. After incubation, the ability of isolates to reduce nitrates to nitrites was determined by the addition of sulfanilic acid followed by $\alpha$-naphthylamine and produces an immediate cherry red color, which was taken as positive for nitrate reduction [32].

\section{Use of carbon and nitration sources}

The ability of the isolates utilizing various carbon sources for energy was studied by following the method recommended by International Streptomyces Project (ISP) [33]. The carbon sources $(1 \% \mathrm{w} / \mathrm{v})$ such as D-Glucose, D-Xylose, L-Arabinose, D-Fructose, D-Galactose, Raffinose, D-Mannitol, Sucrose, Maltose, Lactose, Cellulose were used in the basal medium and the isolates were streaked on the media and then the observations were noted after $7^{\text {th }}, 14^{\text {th }}$ and $21^{\text {st }} d$ by comparing with that of non-supplemented basal medium and on positive control containing D-glucose.

The nitrogen sources such as L-Histidine, Potassium nitrate, LValine, L-Phenylalanine, L-Arginine, and L-Threonine were used to test the ability of the isolates to utilize as nitrogen sources for energy. Each $0.1 \%$ was incorporated in basal media and isolates were streaked on them. After incubation at $27^{\circ} \mathrm{C}$ for $7 \mathrm{~d}$, the growth was observed.

\section{RESULTS}

\section{Sampling and isolation of actinomycetes}

From a total of 12 plastic waste dumped soil samples of Kapuluppada dumping yard, Visakhapatnam (fig. 1), 110 morphologically distinct colonies were obtained on starch casein agar plates. The isolates from each sample collected and their codes were depicted in table 1 . To date, there is no report on the isolation of actinomycetes from this plastic waste dumping area. Hence, the soil samples were collected from this site and made an attempt to isolate actinomycete strains for polyethylene biodegradation.

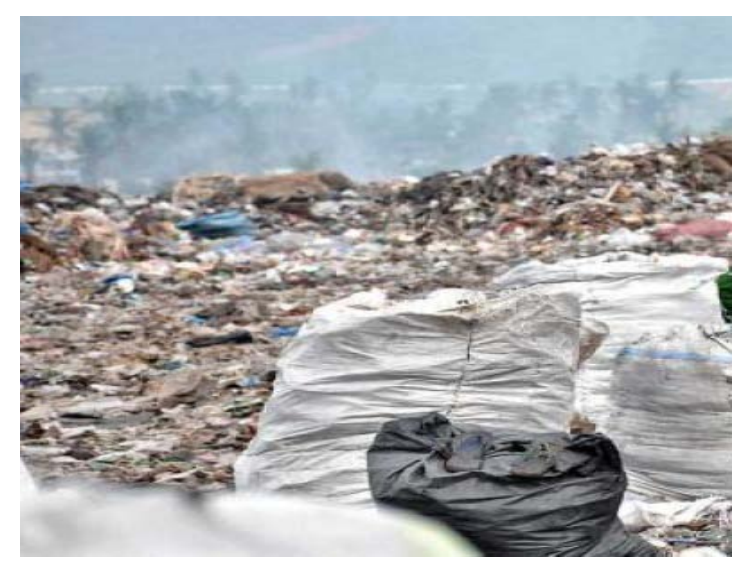

Fig. 1: Place where plastic dumped soil samples were collected

Table 1: Actinomycete isolates from each soil sample collected from Kapuluppada plastic waste dumping yard, near Kommadi, Visakhapatnam

\begin{tabular}{llll}
\hline Sample & Soil depth $\mathbf{( c m )}$ & No. of isolates & Isolate codes \\
\hline 1 & 4 & 8 \\
2 & 7 & 11 & PD1-PD8 \\
3 & 10 & 5 & PD9-PD19 \\
4 & 9 & 6 & PD20-PD24 \\
5 & 6 & 13 & PD25-PD30 \\
6 & 4 & 9 & PD31-PD43 \\
7 & 7 & 9 & PD44-PD52 \\
8 & 10 & 10 & PD53-PD61 \\
9 & 5 & 7 & PD62-PD71 \\
10 & 5 & 9 & PD72-PD78 \\
11 & 4 & 12 & PD79-PD87 \\
12 & 7 & 11 & PD88-PD99 \\
\hline
\end{tabular}

\section{Screening of isolated actinomycetes for their antimicrobial activities}

\section{Primary screening}

As a result of primary screening, all actinomycete isolates were showed antimicrobial activity against one or more test bacteria and fungus (table 2-7). In this study, isolates PD10, PD22, PD36, PD47, PD66 and PD85 were active against both Gram-positive and Gram negative bacteria (table 2). The three isolates (PD5, PD47 and PD66) were active against all fungus used in this study. Among the 110 isolates, eight isolates had shown antagonistic activity against both $S$. aureus NCIM2079 and MRSA (clinical isolate from KGH, Visakhapatnam) (table 2). Moreover, eight isolates had been shown antagonistic activity against $C$. albicans MTCC183 (table 3).

The most promising isolates against human pathogen MRSA were PD66 (16 mm) and PD85 (15.6 mm) when compared to other isolates. The most promising isolates against human pathogen Candida albicans 
were PD10 (20.4 mm), PD47 (22.9 mm) and PD106 (21.5 mm) when compared to other isolates. However, MRSA had shown resistant against PD2, PD4, PD36, PD47, PD79; PD93 isolates whereas C. albicans had shown resistance against PD15, PD35 isolates. The eight isolates, such as PD5 (17.6 mm), PD9 (10 mm), PD10 (16.2 mm) and PD15 (14.5 mm), PD35 (11 mm), PD47 (10), PD66 (8.9 mm) and PD82 (16) have shown the antagonistic activity against $S$. cerevisiae MTCC170 strain when compared to other isolates (table 3).

Table 2: Zone of inhibition (mm) of the Actinomycete Isolates against tested bacteria using perpendicular streak method

\begin{tabular}{|c|c|c|c|c|c|c|c|}
\hline Isolates & E. coli & B. Subtilis & S. aureus & B. pumilis & MRSA & P. aeruginosa & K. pneumonia \\
\hline PD2 & - & $15.4 \pm 0.3$ & $7.5 \pm 0.3$ & $11 \pm 0.3$ & - & $12.6 \pm 0.6$ & $8 \pm 0.5$ \\
\hline PD4 & $8.5 \pm 0.2$ & $12 \pm 0.3$ & $5.4 \pm 0.2$ & $10.2 \pm 0.2$ & - & $16.2 \pm 0.5$ & $6.7 \pm 0.4$ \\
\hline PD9 & $6.8 \pm 0.3$ & $11.4 \pm 0.3$ & $7.2 \pm 0.3$ & $4.8 \pm 0.3$ & $14.2 \pm 0.3$ & $9.6 \pm 0.3$ & - \\
\hline PD10 & $21.2 \pm 0.2$ & $9.6 \pm 0.2$ & $9.4 \pm 0.2$ & $15.5 \pm 0.5$ & $12.8 \pm 0.5$ & $6.4 \pm 0.3$ & $11.9 \pm 0.6$ \\
\hline PD22 & $9.2 \pm 0.2$ & $15.8 \pm 0.7$ & $10.3 \pm 0.2$ & - & $10.8 \pm 0.6$ & $11.6 \pm 0.2$ & $9.5 \pm 0.3$ \\
\hline PD36 & $11.4 \pm 0.2$ & $14.4 \pm 0.6$ & $9.7 \pm 0.5$ & $9.4 \pm 0.5$ & - & $10.5 \pm 0.3$ & - \\
\hline PD47 & $19 \pm 0.6$ & $18.3 \pm 0.3$ & - & $9 \pm 0.6$ & - & $7.5 \pm 0.4$ & $9 \pm 0.4$ \\
\hline PD51 & $9 \pm 0.5$ & $8.4 \pm 0.2$ & $7.5 \pm 0.6$ & $9 \pm 0.2$ & $8 \pm 0.3$ & $9 \pm 0.2$ & $7 \pm 0.6$ \\
\hline PD66 & $13 \pm 0.2$ & $18.6 \pm 0.3$ & $16.5 \pm 0.5$ & $14.9 \pm 0.6$ & $16 \pm 0.2$ & $21.5 \pm 0.3$ & $14 \pm 0.3$ \\
\hline PD70 & $9.8 \pm 0.3$ & - & $6 \pm 0.2$ & - & $5.5 \pm 0.4$ & $8 \pm 0.2$ & $5 \pm 0.4$ \\
\hline PD79 & $10 \pm 0.2$ & $8 \pm 0.3$ & $6.4 \pm 0.3$ & $8 \pm 0.3$ & - & $7 \pm 0.5$ & $7 \pm 0.3$ \\
\hline PD85 & $6 \pm 0.3$ & $5.2 \pm 0.3$ & $4 \pm 0.5$ & $7 \pm 0.2$ & $15.6 \pm 0.6$ & $7.5 \pm 0.6$ & $6 \pm 0.3$ \\
\hline PD93 & $4.3 \pm 0.3$ & - & - & - & - & $5 \pm 0.4$ & $7.2 \pm 0.2$ \\
\hline PD101 & $6 \pm 0.3$ & $8.2 \pm 0.2$ & $6.3 \pm 0.3$ & $8 \pm 0.5$ & $4.5 \pm 0.6$ & $17.5 \pm 0.4$ & - \\
\hline
\end{tabular}

Values are mean \pm SD of three replications; (-) denotes no zone of inhibition.

Table 3: Zone of inhibition (mm) of actinomycete isolates against tested fungi using perpendicular streak method

\begin{tabular}{lllll}
\hline Isolates & C. albicans & A. niger & A. oryzae & P. chrysogenum \\
\hline PD5 & $10 \pm 0.2$ & $6.8 \pm 0.6$ & $8 \pm 0.2$ & $11 \pm 0.3$ \\
PD9 & $9.5 \pm 0.5$ & $7 \pm 0.3$ & - & $6.5 \pm 0.3$ \\
PD10 & $20.4 \pm 0.2$ & $18.6 \pm 0.3$ & - & $17.6 \pm 0.6$ \\
PD15 & - & $5.8 \pm 0.2$ & $15.4 \pm 0.2$ & $10 \pm 0.3$ \\
PD22 & $9 \pm 0.3$ & $10.4 \pm 0.4$ & $8.8 \pm 0.2$ & $16.2 \pm 0.3$ \\
PD35 & - & $8.6 \pm 0.3$ & $11.3 \pm 0.6$ & $10.4 \pm 0.4$ \\
PD47 & $22.9 \pm 0.4$ & $19.4 \pm 0.5$ & $17.6 \pm 0.2$ & $9.8 \pm 0.5$ \\
PD66 & $11.8 \pm 0.2$ & $11.6 \pm 0.2$ & $16.5 \pm 0.4$ & $10 \pm 0.4$ \\
PD82 & $13.1 \pm 0.2$ & $7.4 \pm 0.2$ & $8 \pm 0.3$ & - \\
PD106 & $21.5 \pm 0.5$ & & $10 \pm 0.5$ \\
\hline
\end{tabular}

Values are mean \pm SD of three replications; (-) denotes no zone of inhibition.

\section{Secondary screening}

The crude extracts prepared from 10 potential isolates against bacteria and 9 isolates against fungi by using submerged state fermentation method were subjected to secondary screening by agar well diffusion method. The crude extract of PD2 (13.4 mm), PD66 $(13.4 \mathrm{~mm}$ ) were most active against B. subtilis NCIM2063, PD47 (14.3 $\mathrm{mm}$ ) against E. coli, PD66 (10.4 mm) against S. aureus NCIM2079,
PD66 (12.2 mm), PD85 (11.5 mm) were most active against methicillin-resistant Staphylococcus aureus, PD4 (14.1 mm), PD66 (15.6 mm) were active against Pseudomonas aeruginosa (table 4).

The crude extracts from potential isolates PD10 (19.2 mm), PD47 (19.8 mm), PD106 (19.1 mm) had shown very good activity against C. albicans whereas PD10 (14.6 mm), PD82 $(15.7 \mathrm{~mm})$ were active against $S$. cereviciae (table 5).

Table 4: Zone of inhibition (mm) in secondary screening of crude extracts $(10 \mathrm{mg} / \mathrm{ml})$ produced from submerged fermentation against bacteria by using agar well diffusion method

\begin{tabular}{|c|c|c|c|c|c|c|c|c|c|c|c|}
\hline $\begin{array}{l}\text { Bacteria/ } \\
\text { Isolate }\end{array}$ & PD2 & PD4 & PD9 & PD10 & PD22 & PD47 & PD66 & PD79 & PD85 & PD101 & Ciprofloxacin \\
\hline E. coli & - & $6 \pm 0.2$ & - & $13.7 \pm 0.6$ & $4.8 \pm 0.2$ & $14.3 \pm 0.2$ & $9.8 \pm 0.4$ & $6.5 \pm 0.6$ & - & - & $16.5 \pm 0.3$ \\
\hline B. subtilis & $13.4 \pm 0.2$ & $10.5 \pm 0.2$ & $9.5 \pm 0.3$ & $4.3 \pm 0.5$ & $12.9 \pm 0.3$ & $11 \pm 0.3$ & $13.4 \pm 0.4$ & $5 \pm 0.2$ & - & $5.6 \pm 0.4$ & $15.7 \pm 0.6$ \\
\hline S. aureus & $5 \pm 0.5$ & - & - & $5.4 \pm 0.3$ & $4.4 \pm 0.4$ & - & $10.4 \pm 0.3$ & $5.2 \pm 0.2$ & - & $4 \pm 0.2$ & $19.5 \pm 0.5$ \\
\hline B. pumilis & $10.1 \pm 0.5$ & $7.9 \pm 0.3$ & - & $12.8 \pm 0.2$ & - & $5.6 \pm 0.4$ & $9 \pm 0.4$ & $6.3 \pm 0.2$ & - & $5.9 \pm 0.2$ & $13.2 \pm 0.4$ \\
\hline$M R S A$ & - & - & $10.9 \pm 0.3$ & $9.1 \pm 0.2$ & - & - & $12.2 \pm 0.3$ & - & $11.5 \pm 0.2$ & - & $17.1 \pm 0.2$ \\
\hline P. aeruginosa & $11.8 \pm 0.4$ & $14.1 \pm 0.5$ & $5.6 \pm 0.4$ & - & $6.7 \pm 0.3$ & - & $15.6 \pm 0.3$ & - & - & $14 \pm 0.3$ & $16.6 \pm 0.5$ \\
\hline K. pneumoniae & $5.4 \pm 0.3$ & - & - & $6 \pm 0.2$ & $5.2 \pm 0.4$ & - & $9.3 \pm 0.5$ & - & - & - & $12.7 \pm 0.8$ \\
\hline
\end{tabular}

Control ( $50 \%$ of methanol). Values are mean \pm SD of three replications; (-) denotes no zone of inhibition.

Table 5: Zone of inhibition ( $\mathrm{mm})$ in secondary screening of crude extracts $(10 \mathrm{mg} / \mathrm{ml})$ produced from submerged fermentation against fungi by using agar well diffusion method

\begin{tabular}{|c|c|c|c|c|c|c|c|c|c|c|}
\hline Fungi/Isolates & PD5 & PD9 & PD10 & PD15 & PD35 & PD47 & PD66 & PD82 & PD106 & Cyclohexamide \\
\hline C. albicans & $7.2 \pm 0.2$ & $8.8 \pm 0.3$ & $19.2 \pm 0.4$ & - & - & $19.8 \pm 0.2$ & $9.6 \pm 0.4$ & $10 \pm 0.2$ & $19.1 \pm 0.5$ & $25 \pm 1$ \\
\hline A. niger & - & - & - & $15.4 \pm 0.3$ & $7.1 \pm 0.5$ & - & $14.9 \pm 0.4$ & $8.9 \pm 0.3$ & - & - \\
\hline A. orizae & $5.6 \pm 0.3$ & - & - & $14 \pm 0.3$ & - & $9 \pm 0.4$ & $14 \pm 0.3$ & $12.4 \pm 0.4$ & - & - \\
\hline P. chrysogenum & $10 \pm 0.5$ & - & - & $6.9 \pm 0.3$ & $6 \pm 0.2$ & - & $8.4 \pm 0.2$ & - & - & - \\
\hline S. cereviciae & $17.3 \pm 0.2$ & $8.6 \pm 0.2$ & $14.6 \pm 0.4$ & $11.9 \pm 0.2$ & $8.7 \pm 0.4$ & $6.6 \pm 0.3$ & - & $15.7 \pm 0.5$ & - & - \\
\hline
\end{tabular}

Control ( $50 \%$ of methanol). Values are mean \pm SD of three replications; (-) denotes no zone of inhibition. 
Table 6: Morphological characteristics

\begin{tabular}{|c|c|c|c|c|c|}
\hline Isolates/Media & Culture media & Growth & Aerial mycelium & Substrate mycelium & Pigments \\
\hline \multirow[t]{4}{*}{ PD2 } & Mineral agar & Good & White & Yellow & Yellowish \\
\hline & Starch casein agar & Excellent & White & Yellow & Yellowish \\
\hline & Glycerol yeast extract agar & Very good & White & Yellow & Yellowish \\
\hline & Oatmeal agar & Good & White & Yellow & Yellowish \\
\hline \multirow[t]{4}{*}{ PD4 } & Mineral agar & Very good & White to ash & Dark black & Pale yellow \\
\hline & Starch casein agar & Excellent & White to ash & Dark black & Pale yellow \\
\hline & Glycerol yeast extract agar & Excellent & White to ash & Dark black & Pale yellow \\
\hline & Oatmeal agar & Good & White to ash & Dark black & Pale yellow \\
\hline \multirow[t]{4}{*}{ PD5 } & Mineral agar & Very good & Dark ash & Brown & Yellow to brown \\
\hline & Starch casein agar & Excellent & Dark ash & Brown & Yellow to brown \\
\hline & Glycerol yeast extract agar & Excellent & Dark ash & Brown & Yellow to brown \\
\hline & Oatmeal agar & Good & Dark ash & Brown & Yellow to brown \\
\hline \multirow[t]{4}{*}{ PD9 } & Mineral agar & Very good & Dark ash & Ash & Yellow to brown \\
\hline & Starch casein agar & Excellent & Dark ash & Ash & Yellow to brown \\
\hline & Glycerol yeast extract agar & Excellent & Dark ash & Ash & Yellow to brown \\
\hline & Oatmeal agar & Very good & Dark ash & Ash & Yellow to brown \\
\hline \multirow[t]{4}{*}{ PD10 } & Mineral agar & Good & White & White & None \\
\hline & Starch casein agar & Excellent & White & White & None \\
\hline & Glycerol yeast extract agar & Excellent & White & White & None \\
\hline & Oatmeal agar & Good & White & White & None \\
\hline \multirow[t]{4}{*}{ PD15 } & Mineral agar & Good & Pale red & Grey & None \\
\hline & Starch casein agar & Excellent & Pale red & Grey & None \\
\hline & Glycerol yeast extract agar & Very good & Pale red & Grey & None \\
\hline & Oatmeal agar & Good & Pale red & Grey & None \\
\hline \multirow[t]{4}{*}{ PD22 } & Mineral agar & Good & White to ash & Brown & Brownish \\
\hline & Starch casein agar & Excellent & White to ash & Brown & Brownish \\
\hline & Glycerol yeast extract agar & Excellent & White to ash & Brown & Brownish \\
\hline & Oatmeal agar & Good & White to ash & Brown & Brownish \\
\hline \multirow[t]{4}{*}{ PD35 } & Mineral agar & Good & White & White & None \\
\hline & Starch casein agar & Excellent & White & White & None \\
\hline & Glycerol yeast extract agar & Very good & White & White & None \\
\hline & Oatmeal agar & Good & White & White & None \\
\hline \multirow[t]{4}{*}{ PD47 } & Mineral agar & Excellent & White & Yellow to brown & Pale yellow \\
\hline & Starch casein agar & Excellent & White & Yellow to brown & Pale yellow \\
\hline & Glycerol yeast extract agar & Excellent & White & Yellow to brown & Pale yellow \\
\hline & Oatmeal agar & Good & White & Yellow to brown & Pale yellow \\
\hline \multirow[t]{4}{*}{ PD66 } & Mineral agar & Good & White & Yellow & Yellowish \\
\hline & Starch casein agar & Excellent & White & Yellow & Yellowish \\
\hline & Glycerol yeast extract agar & Excellent & White & Yellow & Yellowish \\
\hline & Oatmeal agar & Good & White & Yellow & Yellowish \\
\hline \multirow[t]{4}{*}{ PD79 } & Mineral agar & Good & Pale yellow & White & None \\
\hline & Starch casein agar & Excellent & White & White & None \\
\hline & Glycerol yeast extract agar & Very good & White & White & None \\
\hline & Oatmeal agar & Good & White & White & None \\
\hline \multirow[t]{4}{*}{ PD82 } & Mineral agar & Good & Chocolate & Black & None \\
\hline & Starch casein agar & Excellent & Chocolate & Black & None \\
\hline & Glycerol yeast extract agar & Very good & Chocolate & Black & None \\
\hline & Oatmeal agar & Good & Grey & Black & None \\
\hline \multirow[t]{4}{*}{ PD85 } & Mineral agar & Good & Dark grey & Brown & None \\
\hline & Starch casein agar & Excellent & Dark grey & Brown & None \\
\hline & Glycerol yeast extract agar & Excellent & Dark grey & Brown & None \\
\hline & Oatmeal agar & Good & Dark grey & Brown & None \\
\hline \multirow[t]{4}{*}{ PD101 } & Mineral agar & Good & White & Black & Dark blue \\
\hline & Starch casein agar & Excellent & White & Black & Dark blue \\
\hline & Glycerol yeast extract agar & Excellent & Pale white & Black & Dark blue \\
\hline & Oatmeal agar & Good & Pale white & Black & Dark blue \\
\hline \multirow[t]{4}{*}{ PD106 } & Mineral agar & Good & Grey & Coffee & None \\
\hline & Starch casein agar & Excellent & Grey & Coffee & None \\
\hline & Glycerol yeast extract agar & Good & Grey & Coffee & None \\
\hline & Oatmeal agar & Good & Grey & Coffee & None \\
\hline
\end{tabular}

\section{Morphological characteristics of selected isolate}

The growth of all the selected isolates was excellent in starch casein agar. The isolates PD4, PD5, PD9, PD10, PD22, PD47, PD66, PD85, and PD101 had shown excellent growth in starch casein agar as well as in glycerol yeast extract agar (table 6). The substrate and aerial mycelium color were varied among the selected isolates (table 6). The isolate PD2 had shown white colored aerial mycelium, yellow colored substrate mycelium, and yellowish diffusible pigments in mineral agar, starch casein agar, glycerol yeast extract agar, and oatmeal agar. The isolate PD4 had white to ash colored aerial mycelium and dark black colored substrate mycelium and pale yellow colored diffusible pigments. The isolate PD9 developed dark ash colored aerial mycelium and ash colored substrate mycelium and yellow to brownish colored diffusible pigments, the isolate PD22 developed white to ash colored aerial mycelium and brownish colored substrate mycelium and brown colored diffusible pigments, the isolate PD66 had developed white colored aerial mycelium and 
yellow colored substrate mycelium and yellowish colored diffusible pigments (table 6). The morphology of the selected isolates was shown in fig. 2.
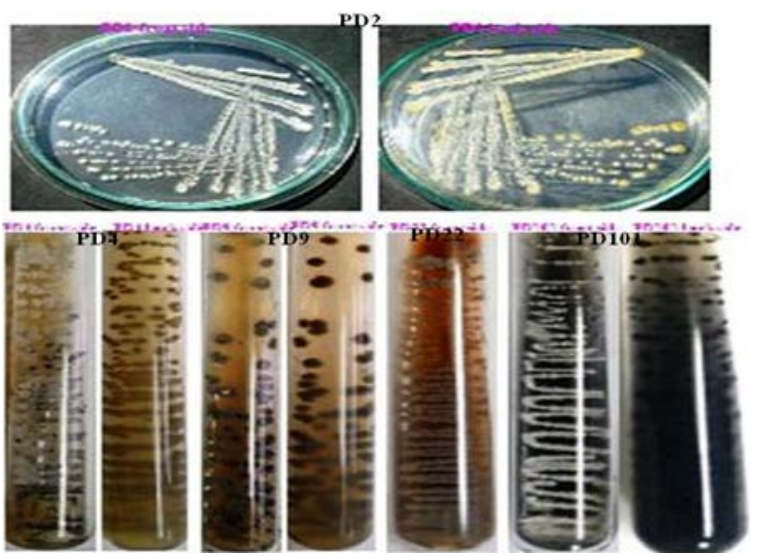

Fig. 2: Morphological appearance of actinomycete isolates

\section{Biochemical characteristics of selected isolate}

Results of the biochemical characteristics indicated that isolates PD4, PD15, PD82 had shown positive results for melanin production, and all the selected isolates showed the ability of starch hydrolysis. The isolates PD4, PD5, PD9, PD15, PD22, PD66, PD79, PD82, and
PD101 were able to hydrolyze both casein and gelatin; the isolates PD2, PD4, PD5, PD9, PD10, PD47, PD66, PD79, and PD106 were shown a positive result for nitrate reduction. The detailed biochemical characteristics of the selected isolates were shown in table 7. The positive results of starch hydrolysis, casein hydrolysis, melanin production test and nitrate reduction test were depicted in fig. 3 .

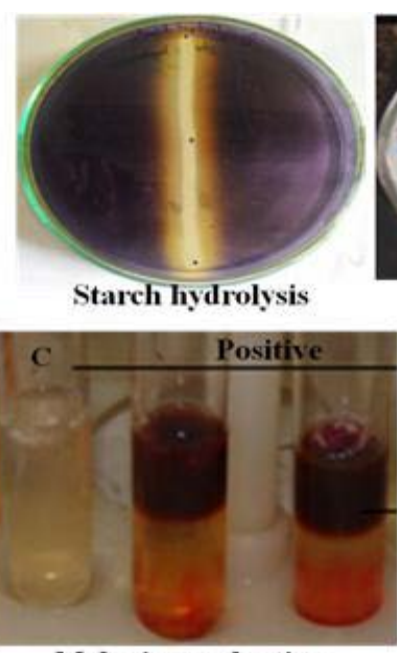

Melanin production

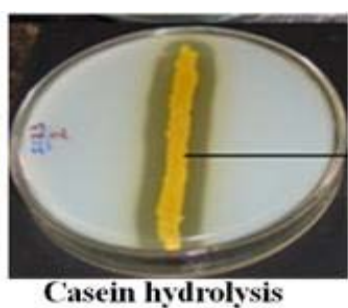

Positive Negaitive

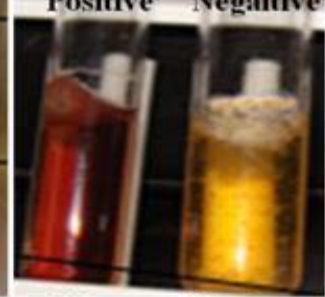

Nitrate reduction
Fig. 3: Biochemical characteristics of the selected isolates

Table 7: Biochemical characteristics of the selected isolates

\begin{tabular}{|c|c|c|c|c|c|c|c|c|c|c|c|c|c|c|c|}
\hline \multirow{2}{*}{ Test } & \multicolumn{15}{|c|}{ Characteristics of isolates } \\
\hline & PD2 & PD4 & PD5 & PD9 & PD10 & PD15 & PD22 & PD35 & PD47 & PD66 & PD79 & PD82 & PD85 & PD101 & PD106 \\
\hline $\begin{array}{l}\text { Melanin } \\
\text { production }\end{array}$ & - & + & - & - & - & + & - & - & - & - & - & + & - & - & - \\
\hline $\begin{array}{l}\text { Nitrate } \\
\text { reduction }\end{array}$ & + & + & + & + & + & - & - & - & + & + & + & - & - & - & + \\
\hline $\begin{array}{l}\text { Starch } \\
\text { hydrolysis }\end{array}$ & + & + & + & + & + & + & + & + & + & + & + & + & + & + & + \\
\hline $\begin{array}{l}\text { Casein } \\
\text { hydrolysis }\end{array}$ & - & + & + & + & - & + & + & + & + & + & + & + & + & + & - \\
\hline $\begin{array}{l}\text { Gelatin } \\
\text { hydrolysis }\end{array}$ & + & + & + & + & + & + & + & - & - & + & + & + & - & + & + \\
\hline $\begin{array}{l}\mathrm{H}_{2} \mathrm{~S} \\
\text { production }\end{array}$ & - & - & - & - & - & - & - & - & - & - & - & - & - & - & - \\
\hline $\begin{array}{l}\text { Peptonization } \\
\text { and } \\
\text { coagulation of } \\
\text { milk }\end{array}$ & + & + & - & - & - & - & + & + & - & - & - & - & + & + & + \\
\hline $\begin{array}{l}\text { Urea } \\
\text { hydrolysis }\end{array}$ & - & - & - & - & - & - & - & - & - & - & - & - & - & - & - \\
\hline
\end{tabular}

' + ' indicates positive result of the test; '-' indicates the negative result of the test

Table 8: Carbon source utilization

\begin{tabular}{|c|c|c|c|c|c|c|c|c|c|c|c|c|c|c|c|}
\hline \multirow{2}{*}{$\begin{array}{l}\text { Carbon } \\
\text { source }\end{array}$} & \multicolumn{15}{|c|}{ Isolates } \\
\hline & PD2 & PD4 & PD5 & PD9 & PD10 & PD15 & PD22 & PD35 & PD47 & PD66 & PD79 & PD82 & PD85 & PD101 & PD106 \\
\hline D-Glucose & + & + & + & + & + & + & + & + & + & + & + & + & + & + & + \\
\hline D-Xylose & + & + & + & + & + & + & + & + & + & + & + & + & + & + & + \\
\hline L-Arabinose & + & + & + & + & + & + & + & + & + & + & + & + & + & + & + \\
\hline D-Fructose & + & + & + & + & + & + & + & + & + & + & + & + & + & + & + \\
\hline D-Galactose & + & + & + & + & + & + & + & + & + & + & + & + & + & + & + \\
\hline Raffinose & - & - & - & - & - & - & - & - & - & - & - & - & - & - & - \\
\hline Meso-Inositol & - & - & - & - & - & - & - & - & - & - & - & - & - & - & - \\
\hline D-Mannitol & - & - & - & - & - & - & - & - & - & - & - & - & - & - & - \\
\hline Salicin & - & - & - & - & - & - & - & - & - & - & - & - & - & - & - \\
\hline Sucrose & + & + & + & + & + & + & + & + & + & + & + & + & + & + & + \\
\hline Maltose & + & + & + & - & - & - & + & + & - & - & - & - & - & + & - \\
\hline Lactose & + & + & + & + & + & + & + & + & + & + & + & + & + & + & + \\
\hline Cellulose & - & - & - & - & - & - & - & - & - & - & - & - & - & - & - \\
\hline
\end{tabular}


'+' indicates carbon source utilization; '-' indicates non-utilization of the carbon source

Table 9: Nitrogen source utilization

\begin{tabular}{|c|c|c|c|c|c|c|c|c|c|c|c|c|c|c|c|}
\hline \multirow{2}{*}{$\begin{array}{l}\text { Nitrogen } \\
\text { source }\end{array}$} & \multicolumn{15}{|c|}{ Isolates } \\
\hline & PD2 & PD4 & PD5 & PD9 & PD10 & PD15 & PD22 & PD35 & PD47 & PD66 & PD79 & PD82 & PD85 & PD101 & PD106 \\
\hline L-Histidine & + & + & + & + & + & + & + & + & + & + & + & + & + & + & + \\
\hline $\begin{array}{l}\text { Potassium } \\
\text { nitrate }\end{array}$ & + & + & + & + & + & + & + & + & + & + & + & + & + & + & + \\
\hline L-Valine & + & + & + & + & + & + & + & + & + & + & + & + & + & + & + \\
\hline L-Arginine & + & + & + & + & + & + & + & + & + & + & + & + & + & + & + \\
\hline L-Threonine & + & + & + & + & + & + & + & + & + & + & + & + & + & + & + \\
\hline
\end{tabular}

'+' indicates nitrogen source utilization; '-' indicates non-utilization of the nitrogen source

\section{Carbon and nitrogen source utilization}

All the selected isolates had been shown to utilize D-Glucose, DXylose, L-Arabinose, D-Fructose, D-Galactose, Sucrose, Lactose as their carbon source, whereas no isolate had shown to utilize the carbon sources such as Raffinose, Meso-Inositol, D-Mannitol, Salicin and cellulose (table 8). All the selected isolates in the present study had shown the utilization of nitrogen sources such as L-Histidine, Potassium nitrate, L-Valine, L-Arginine, L-Threonine (table 9).

\section{Physiological characteristics}

The results of physiological characteristics indicated that all the selected actinomycete isolates had shown excellent growth at $30^{\circ} \mathrm{C}$ and $40^{\circ} \mathrm{C}$, good to moderate at $20^{\circ} \mathrm{C}$ and $50^{\circ} \mathrm{C}$ and at $10^{\circ} \mathrm{C}$ the growth was poor. The isolate PD15 had no growth at $10^{\circ} \mathrm{C}$ (table 10).

The actinomycete isolates had grown excellent at $\mathrm{pH} 7$, good to

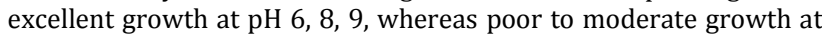
pH 5 was observed (table 11).

Table 10: Temperature

\begin{tabular}{|c|c|c|c|c|c|c|c|c|c|c|c|c|c|c|c|}
\hline \multirow{2}{*}{$\begin{array}{l}\text { Temperatur } \\
\text { e }\end{array}$} & \multicolumn{15}{|c|}{ Isolates } \\
\hline & PD2 & PD4 & PD5 & PD9 & $\begin{array}{l}\text { PD1 } \\
0\end{array}$ & $\begin{array}{l}\text { PD1 } \\
\mathbf{5}\end{array}$ & $\begin{array}{l}\text { PD2 } \\
2\end{array}$ & $\begin{array}{l}\text { PD3 } \\
5\end{array}$ & $\begin{array}{l}\text { PD4 } \\
7\end{array}$ & $\begin{array}{l}\text { PD6 } \\
6\end{array}$ & $\begin{array}{l}\text { PD7 } \\
\mathbf{9}\end{array}$ & $\begin{array}{l}\text { PD8 } \\
2\end{array}$ & $\begin{array}{l}\text { PD8 } \\
5\end{array}$ & $\begin{array}{l}\text { PD10 } \\
1\end{array}$ & $\begin{array}{l}\text { PD10 } \\
6\end{array}$ \\
\hline $10^{\circ} \mathrm{C}$ & + & + & + & + & + & - & + & + & + & + & + & + & + & + & + \\
\hline $20^{\circ} \mathrm{C}$ & ++ & ++ & ++ & ++ & +++ & ++ & + & +++ & ++ & ++ & ++ & ++ & ++ & +++ & ++ \\
\hline $30^{\circ} \mathrm{C}$ & $\begin{array}{l}+++ \\
+\end{array}$ & $\begin{array}{l}+++ \\
+\end{array}$ & $\begin{array}{l}+++ \\
+\end{array}$ & $\begin{array}{l}+++ \\
+\end{array}$ & ++++ & ++++ & ++++ & ++++ & ++++ & ++++ & ++++ & ++++ & ++++ & ++++ & ++++ \\
\hline $40^{\circ} \mathrm{C}$ & & $\begin{array}{l}+++ \\
+\end{array}$ & $\begin{array}{l}+++ \\
+\end{array}$ & $\begin{array}{l}+++ \\
+\end{array}$ & ++++ & ++++ & ++++ & ++++ & ++++ & ++++ & ++++ & ++++ & ++++ & ++++ & ++++ \\
\hline $50^{\circ} \mathrm{C}$ & & ++ & ++ & ++ & ++ & ++ & ++ & ++ & ++ & ++ & ++ & ++ & ++ & ++ & ++ \\
\hline
\end{tabular}

++++Excellent; +++Good; ++Moderate; +Poor

Table 11: pH

\begin{tabular}{|c|c|c|c|c|c|c|c|c|c|c|c|c|c|c|c|}
\hline \multirow[t]{2}{*}{ pH } & \multicolumn{15}{|c|}{ Isolates } \\
\hline & PD2 & PD4 & PD5 & PD9 & PD10 & PD15 & PD22 & PD35 & PD47 & PD66 & PD79 & PD82 & PD85 & PD101 & PD106 \\
\hline 5 & + & ++ & ++ & + & + & + & + & + & + & + & ++ & ++ & + & + & + \\
\hline 6 & ++++ & +++ & +++ & ++++ & +++ & +++ & ++++ & +++ & +++ & ++++ & ++++ & ++++ & ++++ & ++++ & ++++ \\
\hline 7 & ++++ & ++++ & ++++ & ++++ & ++++ & ++++ & ++++ & ++++ & ++++ & ++++ & ++++ & ++++ & ++++ & ++++ & ++++ \\
\hline 8 & ++++ & ++++ & +++ & +++ & ++++ & ++++ & ++++ & ++++ & ++++ & +++ & +++ & ++++ & ++++ & ++++ & ++++ \\
\hline 9 & +++ & +++ & +++ & +++ & ++++ & +++ & ++++ & +++ & +++ & +++ & ++++ & ++++ & ++++ & +++ & +++ \\
\hline
\end{tabular}

++++Excellent; +++Good; ++Moderate; +Poor

\section{DISCUSSION}

Antibiotics are the very important bioactive molecules for the treatment of various pathogenic and autoimmune diseases. Currently, because of the emergencies of multi-drug resistant pathogenic organisms, treatment of resistant pathogens is a challenging problem. For the treatment of multi-drug resistant pathogens, there has been increasing demand for effective antibiotics from soil actinomycetes [34, 35]. Actinomycetes account $70 \%$ of the earth's surface and are a good source for isolation and production of novel and potent bioactive secondary metabolites such as antibiotics [36, 37]. Isolation of novel actinomycetes from the soil is very interesting nowadays to isolate and produce novel bioactive metabolites from waste disposal areas had shown antimicrobial activity against bacteria and fungi [38]. These recent studies motivated the corresponding author of this article to isolate antibiotic producing actinomycetes from Kapuluppada plastic waste dumping yard, near Kommadi, Visakhapatnam (A. P.). This is the first report on the isolation of actinomycetes from plastic dumping area producing an anti-microbial compound against bacteria and fungi. In the present study, the randomly selected 12 plastic waste dumped soil samples were taken for isolation of potent actinomycetes of antimicrobial activity. From the soil samples, a total of 110 actinomycetes were isolated and were used for primary screening against bacteria and fungi using single streak methods. The results indicated that most of the actinomycete isolates showed potential antimicrobial activity against one or more test bacteria and/or fungus (table 2 and 3). Sharma et al. [38] isolated actinomycetes from Pulicat, Muttukadu, and Ennore estuaries and they had shown antibacterial and antifungal activity. Thakur et al. [39] reported that a total of 110 actinomycetes strains were isolated from the soil samples collected from the protected forest soil from two states in Northeast India. The isolates were then characterized by conventional methods and assessed for their antimicrobial activity against test microorganisms. The selected actinomycete isolates had shown dissimilar activities between Gram-positive and Gram-negative bacterial strains. From the results, it was understood that a Gram-positive bacterium was highly susceptible to the tested crude extracts compared to Gram-negative bacteria. This result was 
in agreement with the previous report of Ilic et al.[40]. It has been suggested that different sensitivity between Gram positive and Gram negative bacteria could be ascribed to morphological differences such as, the outer membrane of Gram-negative bacteria having lipopolysaccharide which makes the cell wall impermeable to lipophilic extracts, whereas, a Gram-positive bacterium was more susceptible because of lack of outer membrane. A Clear zone of inhibition around the wells on the inoculated plates is an indication of antimicrobial activities of metabolites extracted from actinomycetes against test organisms. Smriti et al. [41] had shown that a maximum inhibition zone of $14 \mathrm{~mm}$ against tested bacteria. Gurung et al. [42] reported 0-18 mm inhibition zone of crude extracts against selected tested organisms. In the present study, 0$23 \mathrm{~mm}$ inhibition zone of crude extracts from isolated against test organisms was observed, which is higher than the previous reports.

The previous study indicated that the inhibition zone of crude extracts from isolated against MRSAs ranged from 0-15 mm [43]. Whereas in this study, inhibition zone of crude extracts from three isolates against MRSAs ranged from 0-23 $\mathrm{mm}$ which was found to be good when compared to Yucel and Yemac's results [43]. The results of the present study were interesting and encouraging because the crude extracts from the isolates may have promising antibiotics for treatment of pathogenic MRSA and Candida albicans. We have observed greater inhibition zone when compared to crude extracts from the actinomycete isolates from the previous studies. In order to get better inhibition zones, further purification of bioactive metabolite is necessary to get pure antibiotic substance for treatment of different pathogenic microorganisms and it has been suggested for intensive studies on the actinobacterial diversity of plastic waste dumping yard to establish the rich source of actinomycetes diversity and could put an important input into research and pharmaceutical industries.

The color of aerial mycelium, substrate mycelium and diffusible pigments showed distinct variation depending upon the culture medium, in which the selected isolates were grown. Among the four culture media (starch casein agar, glycerol yeast extract agar, mineral agar and oatmeal agar) used, the growth of all the selected isolates was excellent in starch casein. Valli et al. had also observed, white powdery, creamy, pinpoint colonies of actinomycetes [44]. Gebreselema et al. had also reported that the selected antimicrobial actinomycete isolates shown excellent growth in starch casein agar [30]. All the selected isolates in this study had the ability to hydrolyze starch but fail to hydrolyze urea. All the isolates have the ability utilize carbon sources such as D-Glucose, D-Xylose, LArabinose, D-Fructose, D-Galactose, Sucrose, Lactose but fail to utilize Raffinose, Meso-Inositol, D-Mannitol, Salicin, cellulose (table 8) and nitrogen sources such as L-Histidine, Potassium nitrate, LValine, L-Arginine, L-Threonine (table 9) for their cellular energy. The similar results were reported in the study conducted by Sharma and David, 2012 [38] in which actinomycetes were isolated from marine sediments of Pulicat estuary, Muttukadu estuary and Ennore estuary, Tamil Nadu, India. The selected isolates had shown excellent growth at temperature $30-40^{\circ} \mathrm{C}, \mathrm{pH}$ 7-8 (table 10 and 11). The actinomycetes isolated from Pulicat estuary, Muttukadu estuary, and Ennore estuary grow well at temperature $30{ }^{\circ} \mathrm{C}$ and $40{ }^{\circ} \mathrm{C}$ and pH 7.0 to 9.0 [38] whereas the actinomycetes isolated from water and sediments of Lake Tana, Ethiopia, the optimum temperature for the growth of isolates was ranged from 25 to $30^{\circ} \mathrm{C}$ [30]. Therefore, based on the results the selected isolates obtained from Kapuluppada plastic waste dumping yard were grouped under the genera of Streptomyces.

The actinomycete isolates from Kapuluppada plastic waste dumping yard have significant activity against bacteria and fungi and could be useful for many applications such as control of infectious diseases and drug discovery and further studies are focused on standardization of fermentation conditions to improve effective antimicrobial production in liquid medium and isolation of antimicrobial compounds. Further detailed studies on these antimicrobial metabolites have to be carried out for biotechnological applications.

\section{CONCLUSION}

Till date, there is no report on actinomycetes producing antimicrobial compounds from the Kapuluppada plastic dumping yard, Visakhapatnam. Therefore, isolation and screening of actinomycetes may contribute to the discovery of new antibiotics and could fight against antibiotic resistance pathogens. Further, purification and characterization of antibiotics are required for the commercial value of these antibiotics.

\section{ACKNOWLEDGEMENT}

The first author acknowledges Prof. Dr. G. Girijasankar, A. U. College of Pharmaceutical Sciences for his kind cooperation and facilities extended in the Pharmaceutical Biotechnology laboratory to complete this research work. This project is very low budget, and hence all the financial and grants are arranged by the institute.

\section{CONFLICT OF INTERESTS}

Authors declare that we have no conflict of interest

\section{REFERENCES}

1. Berdy J. Bioactive microbial metabolites. J Antibiot 2005;58:126.

2. Ramasamy V, Suban M, Annamalai P. Isolation, characterization and antimicrobial activity of actinobacteria from point climere Coastal region, east coast of India. Int Res J Pharm 2010;1:358-65.

3. Sundaramoorthi C, Vengadesh PK, Gupta S, Karthick K, Tamilselvi N. Production and characterization of antibiotics from soil-isolated actinomycetes. Int Res J Pharm 2011;2:114-8.

4. Gonzalez-Franco CA, Robles-Hernandez RY. Actinomycetes as biological control agents of phytopathogenic fungi. Tecnociencia Chihuahua 2009;3:64-73.

5. Gurung TD, Sherpa C, Agrawal VP, Lekhak B. Isolation and characterization of antibacterial actinomycetes from soil samples of Kalapatthar, Mount Everest Region. Nepal J Sci Technol 2009;10:173-82.

6. Ogunmwonyi IH, Mazomba N, Mabinya L, Ngwenya E, Green E, Akinpelu DA, et al. Studies on the culturable marine actinomycetes isolated from the Nahoon beach in the Eastern cape province of South Africa. Afr J Microbiol Res 2010;4:2223-30.

7. Retinowati W. Identification of Streptomyces sp-MWS1 producing antibacterial compounds. Indonesian J Trop Infect Dis 2010;1:82-5.

8. Khanna M, Solanki $R$, Lal R. Selective isolation of rare actinomycetes producing novel antimicrobial compounds. Int J Adv Biotechnol Res 2011;2:357-75.

9. Maleki H, Mashinchian 0. Characterization of Streptomyces isolates with UV, FTIR spectroscopy, and HPLC analyses. Bioimpacts 2011;1:47-52.

10. Jemimah NSV, Srinivasan M, Devi CS. Novel anticancer compounds from marine actinomycetes. J Pharm Res 2011;4:1285-7.

11. Nonoh JO, Lwande W, Masiga D, Okech MA, Nyende AB, Boga HI. Isolation and characterization of Streptomyces species with antifungal activity from selected national parks in Kenya. Afr J Microbiol Res 2010;4:856-64.

12. Raja A, Prabakaran P, Gajalakshmi P. Isolation and screening of antibiotic producing psychrophilic actinomycetes and its nature from Rothang hill soil against viridians Streptococcus sp. Res J Microbiol 2010;5:44-9.

13. Ilic SB, Kontantinovic SS, Todorovic ZB. UV/Vis analysis and antimicrobial activity of Streptomyces isolates. Med Biol 2005;121:44-6.

14. Adwan G, Mhanna M. Synergistic effects of plant extracts and antibiotics on Staphylococcus aureus strains isolated from clinical specimens. Middle-East J Sci Res 2008;3:134-9.

15. Saadoun I, Hameed KM, Moussauui A. Characterization and analysis of the antibiotic activity of some aquatic actinomycetes. Microbios 1999;99:173-9.

16. Narendra K, Ravi KS, Mishra SK, Singh AK, Pachouri UC. Isolation and screening of soil actinomycetes as a source of antibiotics active against bacteria. Int J Microbiol Res 2010;2:12-6.

17. Aghamirian RM, Ghiasian AS. Isolation, and characterization of medically important aerobic actinomycetes in the soil of Iran. Open Microbiol J 2009;3:53-7. 
18. Reddy NG, Ramakrishna DPN, Raja Gopal SV. Morphological, physiological and biochemical studies of marine Streptomyces rochei (MTCC 10109) showing antagonistic activity against human pathogenic microorganisms. Asian J Biol Sci 2011;4:1-14.

19. Waksman SA, Reilly HC, Hariis DA. Streptomyces griseus (Krainsky) Waksman and Henrici. J Bacteriol 1948;56:259.

20. Williams ST, Goodfellow M, Alderson G, Wellington EMH, Sneath PHA, Sackin MJ. Numerical classification of Streptomyces and related genera. J Gen Microbiol 1983;129:1743-813.

21. Hayasaka M, Yoshida Y, Iimura Y. Selective isolation of bioactive soil actinomycetes belonging to the Streptomyces violaceus niger phenotypic cluster. J Appl Microbiol 2004;96:973-81.

22. You JL, Cao LX, Liu GF, Zhou SN, Tan HM, Lin YC. Isolation and characterization of actinomycetes antagonistic to pathogenic vibrio species from near shore marine sediments. World J Microbial Biotechnol 2005;21:679-82.

23. Thenmozhi M, Kannabiran K. Studies on isolation, classification and phylogenetic characterization of novel antifungal Streptomyces sp. VITSTK7 in India. Curr Res J Biol Sci 2010;2:306-12.

24. Sambamurthy R, Ellaiah P. A new streptomycin-producing neomycin (B and C) complex, Streptomyces marinensis (part-1). Hind Antibiot Bull 1974;17:24-8.

25. Pandey B, Ghimire P, Agrawal VP. Studies on the antimicrobial activity of the actinomycetes isolated from the Khumbu region of Nepal. Appl Microbiol 2008;5:235-61.

26. Yang KQ, Han L, Vining LC. Regulation of jadomycin-B production in Streptomyces venezuelae Isp5230-involvement of a repressor gene. J Bacteriol 1995;177:6111-7.

27. Cross T, William ST. Actinomycetes. In: Method in microbiology. 4th ed. London: Academic Press; 1971. p. 29-65.

28. Tiwari KD. Protocol for actinomycetes studies in RLABB 2008/9. Tridhtuven University Tikiriupr: Central Department of Microbiology, Institution of Science and technology; 2009. p. 21.

29. Muiru WM, Mutitu EW, Mukunya DM. Identification of selected actinomycetes isolates and characterization of their antibiotic metabolites. J Biol Sci 2008;8:1021-6.

30. Gebreselema G, Feleke M, Samuel S, Nagappan R. Isolation and characterization of potential antibiotic producing actinomycetes from water and sediments of Lake Tana, Ethiopia. Asian Pac J Trop Biomed 2013;3:426-35.

31. Salle AJ. Laboratory Manual on Fundamental Principles of Bacteriology, Mc Graw-Hill, UK; 1948.

32. Cappuccino JG, Sherman N. Microbiology a Laboratory manua, Addison-Westley Longman, UK; 1996.

33. Shirling EB, Gottlieb D. Methods for characterization of Streptomyces species. Int J Systematic Evolutionary Bacteriol 1966;16:313-40.
34. Abo-Shadi M, Sidkey NM, Al-Mutrafy AM. Antimicrobial agent is producing microbes from some soils' rhizosphere. J Am Sci 2010;6:915-25.

35. Abebe B, Feleke M, Berhanu A. Isolation and screening of antibiotic producing actinomycetes from soils in Gondar town, North West Ethiopia. Asian Pac J Trop Dis 2013;3:375-81.

36. Suthindhiran K, Kannabiran K. Cytotoxic and antimicrobial potential of actinomycete species Saccharopolyspora salina VITSDK4 isolated from the Bay of Bengal Coast of India. Am J Infect Dis 2009;5:90-8.

37. Usha Y, Koppula S, Vishnuvardhan Z. Bioactive metabolites from marine sediments (Streptomyces species) of three coastal areas. Drug Invent Today 2011;2:114-7.

38. Sharma SCV, David E. A comparative study on selected marine actinomycetes from pulicat, muttukadu, and ennore estuaries. Asian Pac J Trop Biomed 2012;2:S1827-S1834.

39. Thakur D, Yadav A, Gogoi BK, Bora TC. Isolation and screening of Streptomyces in the soil of protected forest areas from the states of Assam and Tripura, India, for antimicrobial metabolites. J Med Mycol 2007;17:242-9.

40. Ilic SB, Konstantinovic SS, Todorovic ZB, Lazic ML, Veljkovic VB, Jokovic N. Characterization and antimicrobial activity of the bioactive metabolites in Streptomycetes isolates. Microbiol 2007;76:421-8.

41. Smriti Singh, Pramod Kumar, Gopalan N, Bhuvnesh Shrivastava, Kuhad RC, Hotam Singh C. Isolation and partial characterization of actinomycetes with antimicrobial activity against multidrug resistant bacteria. Asian Pac J Trop Biomed 2012;2:S1147-S1150.

42. Gurung TD, Sherpa C, Agrawal VP, Lekhak B. Isolation and characterization of antibacterial actinomycetes from soil samples of Kalapatthar, Mount Everest Region. Nepal J Sci Technol 2009;10:173-82.

43. Yucel S, Yemac M. Selection of Streptomyces isolates from turkish karstic caves against antibiotic resistant microorganisms. Pak J Pharm Sci 2010;23:1-6.

44. Valli S, Suvathi Sugasini S, Aysha OS, Nirmala P, Vinot Kumar P, Reena A. Antimicrobial potential of actinomycetes species isolated from marine environment. Asian Pac J Trop Biomed 2012;9:416-73.

\section{How to cite this article}

- Midhun Kumar Duddu, Girijasankar Guntuku. Isolation, screening, and characterization of antibiotic producing actinomycetes from kapuluppada plastic waste dumping yard, Visakhapatnam. Int J Pharm Pharm Sci 2016;8(11):221-229. 